\title{
ACCURACY OF USING ENGLISH COLlOCATION IN WRITING DESCRIPTIVE TEXTS AT SMK CAHAYA HARAPAN STUDENTS
}

\author{
Magpika Handayani ${ }^{1)}$, Yovita Angelina ${ }^{2)}$ \\ ${ }^{1)}$ Politeknik Tonggak Equator, Pontianak, Indonesia \\ E-mail: magpikahandayani@yahoo.com \\ ${ }^{2)}$ Politeknik Tonggak Equator, Pontianak, Indonesia \\ E-mail: yovita.angelina89@gmail.com
}

\begin{abstract}
The purpose of this study is to know the accuracy of using English collocation in writing descriptive text. The use of collocation in writing is one of the important things in creating a paper. The correct use of collocation is often a problem in writing. Students often do not use accurate collocation due to differences in collocations held in the first language with collocations in English. The ability to write using accurate collocation might have an impact on the comfort of the reader in understanding the meaning of the writing written. The method used in this research is a descriptive method by describing students' collocation accuracy that is gathered from task and students descriptive writing. Students do not know at all about collocation and the collocation used is Indonesian translated. Descriptive writing of SMK Harapan Harapan students specifically the marketing department that uses collocation is still not coherent, not developed and there are still many errors. Based on the results of the research, the writer found that students understand how to write descriptive text, but they do not understand how to express factual description in their writing with collocation accurately because they are not familiar with the collocation that should be used in English as the target language.
\end{abstract}

Keywords: Collocation; Accuracy; Writing; Descriptive Text

\section{INTRODUCTION}

Having some information related to accuracy in using collocation for writing descriptive text help teacher to prepare appropriate material in their class in teaching English collocation. The use of collocation in writing descriptive text is one of the essential things in writing. The use of correct and accurate collocation in descriptive writing makes writing sound natural and resemble the native speakers of a language. The ability to write using accurate collocation might have an impact on the comfort of the reader in understanding the meaning of the writing. The ability to use collocation correctly in writing shows that a student has the awareness that English has a collocation that cannot be confused with collocation in the first language in his environment. According to Bazzaz \& Samad (2011), there is a significant relationship between the students' collocation understanding with their writing. The study conducted by Bazzaz \& Samad (2011) was related to the writing of the story with collocation. In this study, the writer would like to know how accurate the students use collocation in writing descriptive text because writing a descriptive text requires an accurate expression in order to show a factual description in the text.

The use of incorrect collocation is often a problem in descriptive writing. Students often do not use accurate collocation due to differences in collocations held in the first language with collocations in English (Farghal \& AlHamly, 2007). The use of inaccurate collocation in descriptive writing makes the writing that is written by students sound familiar and does not tend to be difficult to understand. Therefore, the accuracy of the use of collocation by students in writing English texts needs to be described so that problems in using collocation can be solved and student awareness to use accurate collocation can be improved.

Awareness of using correct collocation is difficult to be applied by students in writing because of the first language factor. In order to be able to identify errors in the use of collocations by students in writing, an analysis is needed in order to see the extent to which the accuracy of the use of collocations in writing English text by high school students. 
High school students in general are structured to get writing assignments from the teacher to write English texts. However, the writings that are written by students tend to follow the Indonesian language pattern and even the local language patterns they use in the writing so that it influences the meaning and purpose of the writing.

It is important to know the accuracy of using English collocations in writing descriptive texts at the level of vocational high school students. Vocational high school students learn English, and one of the topics in their class is writing descriptive text that is based on the curriculum of English subject, but their writings tend to be difficult to understand. The difficulty of understanding the purpose of the writing written by students is not only due to incorrect language structure, but also some words are collocated which does not provide a clear meaning.

Cahaya Harapan Vocational School, Tayan Hilir subdistrict is located in Sanggau district and it is the first private vocational high school on the island where the alumni of the school have worked in various companies both local and foreign. The school is located at the end of the district and has not yet had a permanent English teacher. Teachers who teach English at this school are honorary teachers with educational qualifications, not teachers, but are second due to limitations in finding English teachers in the district. The above conditions make the writer interested in seeing and studying the accuracy of using English collocation in writing by students because students have been expected to be able to write and use collocation accurately in order to understand and use English collocation to communicate in writing. In addition, students and many alumni have the opportunity to work with foreign companies and are expected to be able to write reports appropriately.

Student ignorance in making collocation becomes a problem in writing. The existence of inaccuracies in making sentences is often a problem in understanding the meaning of sentences expressed by students. Students are often unaware of the collocation they are using and tend to be fixated on the collocation of Indonesian or regional languages. Students do not realize that the collocation has been written in the first language collocation expressed in words in English to form a new meaning that is not in accordance with the original purpose of writing. The use of inaccurate collocation will have an impact on the reader's understanding of interpreting the writing written. Therefore, the writer is interested in seeing the accuracy and problems in using English collocation in descriptive writing by students on English subjects.

Languages in one country have different patterns from other languages in different countries. These differences result in different meanings when applied to certain languages. However, in foreign language learning theory, differences in the form of language might be done so that similarities in meaning can be achieved so that the language can be used. If a language must have the same form and meaning, the tendency of the language cannot be used in communication because cultural differences and habits may change the meaning of the language (Kreoger, 2005: 1).

The word is a significant component in the process of learning a foreign language. A word will make it easier for someone to understand the meaning of both sentences and written texts from foreign languages learned. Words provide space for foreign language students to develop and gain a lot of knowledge from the knowledge being learned. The word is the basic element of a language that can be understood by users of that language. Humans already know and know a language from words carried from birth. Parents play important role in the development of collocation that is used by students. Mac Whinney, Thiessen \& Saffran (Wagner, 2007: 2) said that since an individual baby is familiar with the word, but the baby is still facilitated by his mother in order to obtain his language naturally. Although still in the listening stage, each individual's word development develops along with his biological development that starts from the age of 3 months beginning with pronunciation. The existence of pronunciation done by a baby shows that humans already need words to start interacting with their environment. This shows that the role of words is very significant in supporting communication.

Each word has its function to contribute to a language. Kreoger (2005: 33) added that syntactic categories distinguish words in a language based on their level. In addition, there are also groups of phrases where there are groups of words that form a group and form constituents. Because words have different categories, the group of phrases will also form different categories based on the word that heads the phrase.

Understanding the differences in a language both in terms of form, meaning, and function enable a person to adapt to the language being studied (Kreoger, 2005: 1). This means that in a language there can be differences in form, meaning, and function, someone who understands the differences will be directed to use the form of the language and understand its meaning so that it can use the target language properly according to the language method (Kreoger, 2005: 2). These differences occur because of environmental factors and the habits of a community informing communication patterns.

Collocation is a phrase consisting of two words that form new meaning and have nothing in common with the original word that forms it. According to Gairn and Redman (2011: 5) Collocation is a word that consists of two words and is juxtaposed, namely the basic word which is a free morpheme and forms a new meaning so that it has a different meaning from the original word that formed it. Collocation is an expression used to express something so that the expression conveyed sounds more natural and has a deeper meaning than using certain basic words because the meaning is not heard naturally and in detail (Gairn \& Redman, 2011: 6).

Collocation might have different forms and different meanings if interpreted literally. However, if one's understanding of the relationship between form and meaning of language is good, the words used to communicate tend to be understood. The different forms of 
language in the source language must be understood in interpreting them in the target language. Different forms in collocation may be translated differently in other languages so that it will change the meaning of the word and the language cannot function in communication (Radford, 2009: 15).

Collocation is a collection of words that already exist and must be translated as a whole and formed from words where the language is used. According to Seretan (2011) words learned by someone not only separate words but also words that are in a group or called collocation. Collocation is a combination of words that form a new meaning that already exists and is used for certain groups in expressing a term. Collocation is a word that is ready to use in communication.

One of the problems faced by non-native English speakers in using collocation may lie in the deficiency of the collocation itself. The collocations used by foreign speakers in writing English are often reduced or added because they are adapted to the existing collocation in their first language. The addition to the word collocation by foreign speakers in the text they write is called overuse. Foreign speakers of English also make mistakes in using collocations by reducing the words that should be in the words they use, and this phenomenon is called underuse. Moreover, foreign speakers of English also often have problems using collocation and there is absolutely no connection with the words referred to in the written collocation. The misuse of collocation is called misuse (Men, 2016: 43).

There is some problem in the use of collocation like overuse and underuse. The phenomenon of overuse and underuse is common in the use of foreign vocabulary both written and oral. This phenomenon appears as a result of the comparison of languages between the first language with the second language learned (Men, 2016: 44). Overuse and underuse in collocation occur as a result of the ignorance of the learners of the second language understanding the meaning of the collocation learned so as to make a wrong translation of the collocation. Therefore, to avoid this phenomenon, a person (L2 learner) must understand and investigate this form of misuse and look for difficulties experienced (Li in Men, 2016: 44).

Apart from the above phenomenon, there are also deficiencies in the use of collocation so that the use of collocation is inaccurate. Misuse is a phenomenon where foreign English speakers (L2 learners) do not pay attention to the relationship between the words used. Foreign speakers tend to use the same word but do not understand the correct context in the use of the collocation. Foreign speakers tend to be influenced by the first language in forming collocations so as to produce words that are different from native speakers where they can easily form collocations and are less likely to make mistakes. Therefore, collocations made by foreign speakers of English tend to be different and strongly influenced by the first language and this makes the sound and meaning of collocation produced inaccurate in its use (Men, 2016: 46).

Collocation is a group of words that have a head and constituent. In supporting the communication, students must understand the constituency that shows a language is developing and does not consist of only one word. The constituents of a language may be different from other languages due to the pattern and structure of sentences in that language. Constituency directs the group to which words in a sentence or phrase are located and what their functions are. Arranging the position of a word in a phrase or sentence so that it forms a meaning that has a function called the word constituent (Kreoger, 2005: 28).

Constituent structures of collocation are based on factors of meaning and potential substitutions can be explained into hierarchies, syntactic categories, and tree diagrams. The hierarchy shows that a word has a vertical relationship with other elements in an element of a language. This vertical relationship shows that certain words are smaller in position than other words or vice versa and the dependence of words that are smaller in position with words that are larger in position is very dominant (Kreoger, 2005: 32).

Collocation is a vocabulary unit that can be interpreted idiomatically where the original word might not mean the same as the word formed in the collocation (Seretan, 2011: 1). A collocation may not be translated literally from the source language to the target language because if this is done it can lead to a strange or meaningless meaning. The use of collocation in the process of forming sentences so that the sentence sounds like the original is very crucial because it is very helpful for someone in learning a language.

Collocation is a language phenomenon that has been discussed since ancient Greek times. Collocation means a collection of words in a language that is remembered as a unit that forms constituents so that they can be used smoothly and make it easier for someone to tell a sentence (Seretan, 2011: 9). Collocation is a group of words that can be relied on and helps one to speak the target language correctly and naturally. Collocation is naturally meaningful as expressed by native speakers and all languages have collocation.

The role of collocation in a language is inseparable from the context of the language used (Seretan, 2011: 10). Context plays an important role so that collocation can be interpreted and used besides collocation is a term used to express a relationship of words in the source language with the target language being studied or called an affinity. Affinity in a particular language is used to find natural equivalents to express terms in a particular language and juxtaposed with similarities in form, function, and meaning in the language being studied (Seretan, 2011: 10).

In order to be accepted as a language that can be applied in communication, collocation must be simultaneously and continuously and be a combination of languages that are accepted by the community to pre-form communication. This phenomenon occurs as the development of a language and terms that are widely disseminated by certain groups to easily say something. The collocation of a language is a statement that is used and used in certain communities, (Seretan, 2011: 11). 
Students tend to master collocation because students can easily master words in groups, not individually. Words that are mastered in groups have given certain meanings and functions so that they can be easily used and the meanings are not in conflict with the original language. Therefore, sangta collocation is important to be mastered by students and can be easily mastered in order to improve the mastery of a language.

Collocation is the fixed expression that is formed from the habit of social communication. Seretan (2011: 15) states Collocations are prefabricated phrases. Collocations emerged from studies on language acquisition showing that children memorize not only words in isolation, but also, to a large extent, groups (or chunks) of words. These chunks are viewed as building blocks of language. They are available to speakers as ready-made or prefabricated units, contributing to conflicting and naturalness to their utterances.

Words that are already existed and mastered by students through collocation are words that are ready to use and may help efficient communication. The word that is ready to use helps students to confidently use it without hesitation because it has been determined. After all, the formation of the word is done by native speakers. The word that is ready to use sounds natural because it does not contradict the meaning expressed by the native fitter. Some examples of collocations that are formed as habits and are used in English can be seen in Table I.

TABLE I

THE ELEMENT OF COLLOCATION

\begin{tabular}{cll}
\hline No & Collocation & Structure \\
\hline 1 & Accept defeat & Verb + noun \\
2 & Bad Breath & Adjective + noun \\
3 & Call a meeting & Verb + noun \\
4 & Dead end job & Adjective + noun \\
5 & A huge profit & Adjective + noun \\
6 & A pocket & Noun + noun \\
& calculator & \\
7 & Learn a foreign & Verb + adjective + \\
& language & noun \\
8 & Live dangerously & Verb + adverb \\
9 & Half understand & Adverb + verb \\
10 & Completely soaked & Adverb + adjective \\
11 & Speak through an & Verb + preposition + \\
& interpreter & noun \\
\hline Source: & Lewis (2000: 51) Teaching collocation
\end{tabular}

From some of the examples above it can be concluded that the word "accept defeat" has a meaning close to accepting defeat. It means that the grouping of words can be interpreted literally but the word "accept defeat" in English cannot be replaced with "receipt defeat". Accept defeat is a word that has been processed naturally by native speakers of the language. Likewise, the word "Bad breath" cannot be replaced by "Bad breath", "call a meeting" cannot be replaced by "invite the meeting". "Dead end job" is more commonly used than "Bad end job". This is a natural formation carried out by native speakers of a language which when replaced with certain words will give ambiguous or even meaningless meaning.
In relation to the use of collocation in writing descriptive text, one genre in writing is descriptive. Descriptive writing is writing that describes both human and an object and describes or describes a certain object through words that can stimulate the five senses so that the reader seems to witness or feel the object described by the author himself. Descriptive text is the most widely used type of text and has varied functions in an article (Knapp \& Watkins, 2005: 97). Descriptive text is used as a medium to describe a person or place and the characteristics of something or an animal. Broadly speaking, the description of the text is the text that describes a phenomenon that occurs both factually and nonfactually.

In writing descriptive writing, the present tense is used because it deals with factual and non-factual descriptions of things. However, the simple past tense is also a statement of the dominant time used in descriptive to describe something that has happened that is factual (Knap \& Watkins, 2005: 99). In describing things, relational verbs are used when they want to describe the appearance, quality, and function of a phenomenon. According to Knapp \& Watkins (2005: 92), the structure of descriptive paragraph writing is divided into 3 , namely a thesis describing the main sentence and its discussion, then an argument containing an explanation and elaboration and other explanations related to the test, and a summary consisting of conclusions and re-statements of the phenomenon described.

In general, teachers often judge writing errors from grammatical aspects only. However, it often ignores the competence of student collocation. According to Lewis (2000: 49), the lack of competence in understanding collocation results in students experiencing grammatical errors because long written phrases tend to violate the structure of written sentences and words. Words that are written tend to be wrong and do not fit the purpose commonly used in the target language. Teachers tend to focus on grammar which basically does not provide changes in writing made by students. According to Lewis (2000: 49), many of the students have brilliant ideas, but because of limited words or ignorance of the words used, this results in the mistaken writing of sentences in the text. Lewis (2000: 56) stated that collocation is an important factor in all types of writing because the compatibility of a word in a text makes the text easily understandable.

Based on the students' collocation knowledge and the students writing ability that is described above, the writer in this study would like to know the accuracy of using collocation by students in writing descriptive text. The use of accurate collocation in writing descriptive text is supposed to give clear information and a strong description to readers. Furthermore, the use of accurate collocation in descriptive writing shows the writer's English vocabulary level.

\section{Methodology}

The method in this study is descriptive research by describing students' problems and gathering information about the problems faced. By conducting this research, the 
writer intends to provide an overview of the problems faced by students of SMK Harapan Harapan, Tayan Hilir District, Sanggau Regency. Therefore, the participants of this research are students of SMK Harapan Harapan. This school is chosen because the school program requires students to be able to use collocation related to ability in writing descriptive text. In addition to these reasons, it is often found that students at the school have obstacles in understanding and using collocation in writing descriptive text in English class. The number of students at SMK Cahaya Harapan is 300 students. In this study, the writer selected 30 participants to involve in the research to know their collocation accuracy that is taken from each level in the school. Mulyatiningsih (2013: 10) stated that the sample is a part of the population but the conclusion of the research results applied to all populations.

\section{A. Techniques of data collecting}

In doing this research, the writer gave the task to students to translate the phrase in Bahasa Indonesia into English with collocation, and the students also instructed to write the descriptive text so that the writer gets information that suits the needs of the writer in obtaining students' knowledge about collocation in writing descriptive text. The writer gave several choices of themes to help students determine the topics to be discussed, then the writer distributed worksheets so students can write on the sheets that have been provided (Lodico \& Voegtle, 2010: 123). After finish translating the phrase into English and writing the descriptive text, students then submit the results of their writing for further study about the accuracy of using collocation in the descriptive text of students of SMK Cahaya Harapan.

\section{B. The instrument of Data Collecting}

The instrument of data collecting in this writing is worksheets in the form of question sheets of collocation and writing instructions. According to Mirhosseini (2017: 149), worksheets are the main data sources used to identify important areas that must be met by the writer in order to describe the object of research naturally. By using a worksheet, the writer obtained natural results in order to describe objective results.

\section{Data Analysis}

The data obtained is data that illustrates the ability to write collocation accurately, and then the data is analyzed and reduced to make it easier for writers to see the results of the research. Then the reduced data is interpreted in accordance with the holistic table to see the understanding of collocation of students in writing descriptive text so that it can be conveyed as information from the results of the study. The writer uses a holistic table as a reference in analyzing data because a holistic table helps the reader in understanding the results of research in accordance with predetermined descriptions.

\section{RESULTS AND DISCUSSION}

\section{A. Understanding of Student Collocation}

To see the understanding of the collocation of students of SMK Harapan Harapan, the writer provided 12 collocations in Indonesian that relate to the portrayal of a place or region of interest to them. Students are asked to convert the word collocation in Indonesian into the appropriate collocation in English. 30 students were asked to give their answers in this study, and to find out students' collocations accuracy in writing descriptive text, the writers describe the students' answers one by one. The result of students' answers related to accuracy in using collocation is displayed in Table II.

TABLE II

ACCURACY OF STUDENTS' COLLOCATION

\begin{tabular}{cccc}
\hline Question & $\begin{array}{c}\text { Students' } \\
\text { answer }\end{array}$ & Frequency & Informant \\
\hline Question 1 & Accurate & 5 & 30 \\
& Inaccurate & 25 & \\
\hline Question 2 & Accurate & 5 & 30 \\
& Inaccurate & 25 & 30 \\
\hline Question 3 & Accurate & 3 & \\
& Inaccurate & 27 & 30 \\
\hline Question 4 & Accurate & 4 & 30 \\
& Inaccurate & 26 & 30 \\
\hline Question 5 & Accurate & 2 & 30 \\
& Inaccurate & 28 & \\
\hline Question 6 & Accurate & 5 & 30 \\
& Inaccurate & 25 & \\
\hline Question 7 & Accurate & 9 & 30 \\
& Inaccurate & 21 & \\
\hline Question 8 & Accurate & 5 & 30 \\
& Inaccurate & 25 & 30 \\
\hline Question 9 & Accurate & 3 & \\
& Inaccurate & 27 & 30 \\
\hline Question 10 & Accurate & 4 & \\
& Inaccurate & 26 & 5 \\
\hline Question 11 & Accurate & 5 & \\
& Inaccurate & 25 & 4 \\
\hline Question 12 & Accurate & 26 & \\
& Inaccurate & & \\
\hline
\end{tabular}

Based on Table II, it can be concluded that the understanding of the collocation of SMK Cahaya Harapan students in particular the marketing department is still weak because the number of students who write collocation accurately is less than those who write collocation inaccurately. It can be seen from the number of correct answers written by students in writing accurate collocation in English from Bahasa Indonesia. As it is stated by Men (2016) One of the problems faced by non-native English speakers in using collocation may lie in the deficiency of the collocation itself. The collocations used by foreign speakers in writing English are often reduced or added because they are adapted to the existing collocation in their first language. The addition to the word collocation by foreign speakers in the text they write is called overuse. Foreign speakers of English also make mistakes in using collocations by reducing the words that should be in the words they use, and 
this phenomenon is called underuse. Moreover, foreign speakers of English also often have problems using collocation and there is absolutely no connection with the words referred to in the written collocation. The misuse of collocation is called misuse. Students do not know at all about collocation and the collocation used is Indonesian translated. It requires students to be able to use the semantic area of the word (Mukoroli, 2011). Some students who already have a good understanding can use collocation correctly but there is still the possibility of an error and the meaning of the collocation in question is still not very clear. Students do not understand collocation resulting in the inability of students to write well especially writing descriptive texts. This phenomenon appears as a result of the comparison of languages between the first language with second language learning (Men, 2016: 44).

\section{B. Student Descriptive Writing}

To see the descriptive writing of SMK Cahaya Harapan students, the writer asks students to write descriptive paragraphs that relate to an interesting place and region around them. 30 students were asked to write descriptive texts in this study and to find out the descriptive writing of SMK Cahaya Harapan students, the writer interpreted the students' answers one by one. The descriptive writing descriptions of SMK Cahaya Harapan students using collocation are from 1 to 30 . Based on observations on the results of student work it can be concluded that the descriptive writing of SMK Cahaya Harapan students specifically marketing majors who use collocation is still not coherent, not developed and there are still many errors that are caused by the use of tenses in expressing factual description. As it is stated by Knap \& Watkins (2005: 99), the present tense is used because it deals with factual and non-factual descriptions of things. However, the simple past tense is also a statement of the dominant time used in descriptive to describe something that has happened that is factual. It is because collocations made by foreign speakers of English tend to be different and strongly influenced by the first language and this makes the sound and meaning of collocation produced inaccurate in its use (Men, 2016: 46).

\section{Holistic Description of Student Collocation and Descriptive Writing}

In writing descriptive texts, students must use the correct collocation so that the sound of the writing becomes more natural and easier to understand. To make it easier for readers to understand the results of this study, the writer uses holistic scoring to see the students 'understanding of collocation and students' descriptive writing in describing a place or area that they like. The results of the holistic analysis of collocation and descriptive quizzes of SMK Cahaya Harapan students can be seen in Table III.
TABLE III

Holistic TABle ON STUdENTS COLLOCATION AND DESCRIPTIVE TEXTS

\begin{tabular}{llllllll}
\hline & \multicolumn{7}{c}{$\begin{array}{c}\text { Students' understanding of using } \\
\text { collocation }\end{array}$} \\
\cline { 2 - 7 } & & 1 & 2 & 3 & 4 & 5 & 6 \\
\hline 1 & & & & & & \\
\hline & 2 & & & & & & \\
\hline & 3 & 9 & 1 & & & & 1 \\
\hline & 4 & & & & & & \\
\hline & 5 & & & & & 1 & 6 \\
\hline & 6 & 4 & 3 & & & 5 \\
\hline
\end{tabular}

The holistic table above shows the accuracy in using collocation and writing descriptive texts. The students' understanding of using collocation and descriptive writing can be described as follows:

1. There are 9 students whose writing organization and development are unclear, and the supporting data are insufficient, errors may occur and in the case of collocation, there are many errors in using collocations and not in accordance with the English equivalent. It is because of the lack of competence in understanding collocation results in students experiencing grammatical errors because long written phrases tend to violate the structure of written sentences and words (Lewis, 2000: 49).

2. There is one student whose writing organization and development are unclear, and supporting data is insufficient, an error might occur. In the case of Placement of collocation does not fit the context of writing and not in accordance with grammar.

3. There is one student whose writing organization and development is unclear, and the supporting data is insufficient, there may be an error, but the Collocation used is appropriate and detailed in supporting ideas and students master the use of collocation.

4. There is one student who is known that the descriptive written text has been prepared and developed properly and the use of collocation is correct but there is still the possibility of an error and the meaning of the collocation in question is still not very clear.

5. There are 6 students are known that descriptive written text has been well-developed and developed.

6. There are 4 students are known that the text has been well planned and has been well developed consistent language use. But there are many mistakes in using collocation and it is not in accordance with the English equivalent.

7. There are 3 students are known that the text has been well planned and has been well developed, the use of consistent language. In the case of collocation, the placement of the collocation does not fit the context of the writing and does not conform to grammar.

8. There are 5 students whose texts have been well planned and well developed, the use of language is consistent, and the collocation used is appropriate and detailed in supporting ideas, and students master the use of collocation. 


\section{CONCLUSIONS}

\section{A. Conclusions}

The understanding in using collocation of SMK Harapan Harapan students specifically marketing majors is still weak. Students have no knowledge at all about collocation and the collocation used is Indonesian translated. Some students who already have a good understanding can use collocation correctly but there is still the possibility of an error and the meaning of the collocation in question is still not very clear. Students do not understand collocation resulting in the inability of students to write well especially writing descriptive texts. To find out how students' descriptive writing, the following authors draw based on the results of student writing. Descriptive writing of SMK Harapan Harapan students' specifically the marketing department that uses collocation is still not coherent, not developed and there are still many errors. Based on the holistic scoring above, the authors conclude that in understanding collocation and writing descriptive texts, understanding collocation and descriptive writing of SMK Cahaya Harapan students can be described as follows: There are 9 (Nine) students whose writing and development organizations are unclear, and supporting data are insufficient, there may be errors and in the case of collocation there are many errors in using collocation and it is not in accordance with the English equivalent. There is 1 student whose writing organization and development are unclear, and supporting data is insufficient, an error might occur. In the case of collocation Placement of collocation does not fit the context of writing and not in accordance with grammar. There is one student, whose writing organization and development are unclear, and the supporting data is insufficient, there may be an error, but the Collocation used is appropriate and detailed in supporting ideas and students master the use of collocation. There is one student who is known that the descriptive text has been compiled and developed well and the use of collocation is correct but there is still the possibility of an error and the meaning of the collocation in question is still not very clear.

There are 6 students who are known that descriptive written text has been well-developed and developed. There are 4 students who are known that the text has been well planned and has been well developed, the use of language that is consistent. But there are many mistakes in using collocation and it is not in accordance with the English equivalent. There are 3 students who are known that the text has been well planned and has been well developed, consistent use of language. In the case of collocation, the placement of the collocation does not fit the context of the writing and is not in accordance with grammar. There are 5 students whose texts have been well planned and well developed, the use of language is consistent, and the collocations used are appropriate and detailed in supporting ideas, and students master the use of collocation.

\section{B. Suggestions}

The following are suggestions that the writer would like to provide based on the students and the conditions that the writer obtain directly in the field. For schools, it is supposed to provide flexibility to teachers to practice that can support students to get a lot of vocabulary. For the teacher, it is supposed to compile a list of commonly used collocations so students know about collocations in English so that students can use these collocations correctly in writing. For students, they are expected to be more creative in finding English equivalents in dictionaries and from the internet in order to get a lot of collocation references related to English collocation.

\section{REFERENCES}

Bazzaz, F. E., \& Samad, A. A. (2011). The Use of Verb Noun Collocations in Writing Stories among Iranian. English Language Teaching, 158-163.

Farghal, M., \& Al-Hamly, M. (2007). Lexical Collocations in EFL Writing. The Journal of Asia TEFL, 4(2), 69-94.

Gairn, Ruth\& Redman, Stuart. (2011). Idiom and Phrasal verb. Intermediate. USA: Oxford University Press.

Knapp, Peter \& Watkins, Megan. (2005). Genre, Text, Grammar. Australia: New South Wales Press.

Kreoger, Paul R. (2005). Analyzing Grammar. An Introduction. Cambridge UK: University Press.

Lewis, Michael (2000). Teaching Collocation. Kentucky; UK. Cengage Learning EMEA.

Lodico, Marguerite G \& Voegtle, Katherine H. (2010). Methods in Educational Research. From Theory to Practice. San Francisco. USA.

Men, Haiyan. (2016). Vocabulary increased and collocation learning. A corpus-based cross-sectional study of Chinese learner of English. China: Springer.

Mirhosseini, Seyyed Abdolhamid. (2017). Reflection on qualitative research in language and literacy education. Iran: Springer.

Mukoroli, J. (2011). Effective Vocabulary Teaching Strategies For The English for English for Academic Purposes ESL Classroom. Vermont: SIT Graduate Institute.

Mulyatiningsih, Endang. (2013). Metode Penelitian Terapan Bidang Pendidikan. Bandung: Alfabeta.

Radford, Andrew. (2009). An Introduction to English Sentence Structure. UK: Cambridege University Press.

Seretan, Violeta. (2011). Syntac- Based Collocation Extraction. Text, speech, language and technology series. New York: Springer.

Wagner, Richard K, Muse, Andrea E \& Tannenbaum, Kendra R. (2007). Vocabulary Acquisition. Implication for reading Comprehension. London: The Guilford Press. 